\title{
Financial System Stability and Economic Growth in Nigeria
}

Isaac Ikeafe NJANG

Federal University Lafia

\section{Eko Eko OMINI}

Federal University Lafia

Festus Victor BEKUN

Gelisim Universitesi

Festus Fatai Adedoyin ( $\nabla$ fadedoyin@bournemouth.ac.uk)

Bournemouth University https://orcid.org/0000-0002-3586-2570

\section{Research}

Keywords: economic growth, financial stability, financial system, principal component analysis

Posted Date: February 21st, 2020

DOI: https://doi.org/10.21203/rs.2.24249/v1

License: (c) (i) This work is licensed under a Creative Commons Attribution 4.0 International License. Read Full License 


\title{
Financial System Stability and Economic Growth in Nigeria
}

\author{
Isaac Ikeafe NJANG ${ }^{1}$, Eko Eko OMINI ${ }^{2}$, Festus Victor BEKUN ${ }^{3}$, Festus Fatai \\ ADEDOYIN*4
}

\begin{abstract}
This study primarily seeks to evaluate the influence of financial system stability on economic growth in Nigeria from 1986 to 2016. Employing the use of Principal Component Analysis (PCA), this study constructs a Financial System Stability Index (FSSI) as measurement for financial stability. The indicators used in building the index capture three sectors of the Nigerian Financial System (NFS). The three sectors cover the banking sector, the capital market, the external sector and include a fourth component representing financial depth. The resulting index serves as a single qualitative measure for evaluating the level of stability in a nation's financial system and proves capable of warning of an eminent financial crisis. Employing the use of four macroeconomic indicators, the index is then regressed against the Nigerian economic growth rate with an aim of discovering the short-run and long-run dynamics existing between both variables. The granger causality test, Johansson Cointegration test and Vector Error Correction Model (VECM) are the estimation techniques employed in achieving the objectives of this research. The granger causality test revealed a uni-directional causality between financial stability and economic growth in Nigeria. The Johansson Co-integration test showed that long-run co-integration relationship exists between financial stability and economic growth. Finally, the VECM results find that financial stability displays a negative relationship with economic growth and bears no significant effect on economic growth in Nigeria. The findings disclose that financial stability in Nigeria may be high and has resulted in the underutilization of financial assets thus hampering sustainable economic growth in Nigeria. In conclusion, the outcome of the findings shows that while financial stability may be necessary for initiating economic growth, it is not sufficient for sustaining economic growth in Nigeria. This research work recommends that the FSSI be employed as an additional tool for measuring the condition/state of financial stability in Nigeria and in predicting the onset of a potential financial crisis. The study further recommends that financial authorities must give attention to other aspects of financial development to facilitate sustainable economic growth in Nigeria.
\end{abstract}

\footnotetext{
${ }^{1}$ Department of Economics, Federal University of Lafia, Lafia, Nasarawa State, Nigeria, Faculty of Social Science njangisaac@gmail.com

${ }^{2}$ Department of Economics, Federal University of Lafia, Lafia, Nasarawa State, Nigeria, Faculty of Social Science ekoomini@gmail.com

${ }^{3}$ Faculty of Economics Administrative and Social sciences, Istanbul Gelisim University, Istanbul, Turkey and Department of Accounting, Analysis and Audit, School of Economics and Management, South Ural State University, 76, Lenin Avenue., Chelyabinsk, Russia 454080. fbekun@gelisim.edu.tr

${ }^{4}$ Department of Accounting, Economics and Finance, Bournemouth University, United Kingdom. fadedoyin@bournemouth.ac.uk *corresponding author
} 
Keywords: economic growth, financial stability, financial system, principal component analysis.

JEL Codes: E42, E58, O40

\section{Introduction}

The global financial and economic crisis (GFC) that instigated the failure of most financial institutions across the world in 2007/2008 awoke economists, financial authorities and regulators cum the international financial and economic society to two main realities. First, there is limited research and empirical evidence regarding the nexus between financial stability and economic growth. Secondly, the global financial crisis of 2007/2008 exposed the vulnerabilities of financial systems across the world as a result of globalization, technological innovations and universal integration of domestic financial institutions thereby, increasing the level and scope of systemic risks in financial systems of the world (Blake, Keller, Moynihan, Elliot, Black \& Wyman 2017).

Over the years, financial authorities gave prominence to micro-prudential indicators of financial stability. The objective of this approach was directed towards averting bankruptcy of individual financial firms within the financial system (Udom et al, 2018). The narrative was, financial crisis/instability occurred as a result of unstable and bad financial institutions. Conversely, the two episodes of financial crisis that occurred within the space of a decade (Asian financial crisis of 1997 and the GFC that occurred in 2007/08) differed with this belief. Financial institutions in modern times have increasingly become more inter-connected and interrelated with the advent of technological advancement and globalization. Furthermore, past spells of financial crises have shown that financial crisis are usually preceded by an economic boom before a burst, a condition referred to as the boom burst cycle. Thus, the insolvency in one financial firm triggers a systemic failure in the financial system and usually with second round negative effects on economic growth. This divergence in narrative and experience saw the birth of the macro-prudential policy as a replacement for the micro-prudential indicators by the IMF, and subsequently Central Banks all over the world started adopting this new approach. The Central Bank of Nigeria (CBN) launched the maiden edition in January 2009 and specified four pillars that form the blueprint of financial reforms in the Nigerian Financial System (NFS). They comprise; enhancing the quality of banks, establishing financial stability, enabling the evolution of a healthy financial sector and ensuring that the financial sector contributes to the real economy (CBN, 2009). 
The macro-prudential approach encompasses an all-inclusive slant to monitoring the soundness of the entire financial system by examining macroeconomic and market-based data, alongside qualitative and structural information. The macro-prudential policy is basically a mixture of several components which are; Financial Soundness Indicators (FSI), Macroeconomic data (prices, interest rate and inflation rate), Market based data (stock prices and capital market indices) and they reflect the subcomponents of the financial system (Cheang \& Choy, 2009).

In-retrospect, the Nigerian Financial System (NFS) has experienced and survived through two periods of financial crises that affected most of her financial institutions between the periods 1986 to 2014. The first spanned a period of 1991-1995, after the Structural Adjustment Programme (SAP) in 1986. The second, prompted by the global financial meltdown lasted between 2007-2009 (Obienusi \& Obienusi, 2015). The SAP reforms marked a new era in Nigeria's financial sector and aimed to deregulate the NFS. Prior to the reforms in 1986, economic growth rates in 1983, 1984, 1985 and 1986 recorded consistent negative growth rates from $-5.05 \%,-2.02 \%,-8.32 \%$ and $-8.75 \%$ respectively (Knoema, 2017). However, after implementation, economic growth rate increased to 7.5\%, 6.4\% and 12.0\% in 1988, 1989 and 1990 respectively (the boom) (Orji, Ogbuabor, \& Anthony-orji, 2015).

The Bank consolidation exercise in 2004/2005 was aimed at enhancing the stability of the financial system by increasing the paid up capital for banks from N2billion to N25billion (Soludo, 2004). The reform had immense improvement in the NFS as it resulted in a more diversified financial sector and improved the contribution and role of other non-bank financial institutions. Prior to the reforms in 2004, economic growth recorded at 6.7\%, 14.6\%, 9.5\% and 10.4\% in 2001, 2002, 2003 and 2004 respectively (International Monetary Fund, 2017). Albeit, the post-consolidation years of 2006 to 2008 did not reveal significant improvement in growth compared to the pre-consolidation years, as the average economic growth rate was recorded at 7.0\%. The impact of the 2004/2005 reform reverberated in the capital market, as the Nigerian Stock Exchange (NSE) market was considered to be 'one of the best performing' market in the world in 2007, with market capitalization of bank stocks increasing nine-fold during this time (CB N, 2009).

The Nigerian economy and NFS experienced dramatic improvements during the post SAP and post consolidation era. The development and growth recorded in the Nigerian Financial system and economic performance stands as testament of the positive impact of the financial reforms. However, within the space of three to five years, the growth and development recorded had 
retrogressed. Economic growth rate attained a maximum value of $12.0 \%$ in 1990 but plummeted to $-0.6 \%$ in 1991, five years after SAP. During this period, the NFS underwent a tumultuous period as a considerable number of banks became bankrupt and the economy officially slipped into a recession (the burst). The post consolidation era revealed a similar trend although with a slight difference. While the NFS and economic performance were adversely affected during the $1989 / 1990$ crisis, in the case of the GFC, initial adverse effects were suffered only in the NFS. In fact, economic growth remained relatively stable as it was recorded at 6.7\%, 7.3\%, 7.2\%, 8.4\% and 11.3\% in 2006, 2007, 2008, 2009 and 2010 (IMF, 2017). On the other hand, the stock market experienced a massive setback as it had lost approximately $70 \%$ of its value in 2008/2009 (the burst) (CBN, 2009). Eventually, in 2011, five years after the recapitalization reforms, economic growth rate took a nosedive to $4.9 \%$ as the CBN implemented the macro-prudential policy.

Over the years, several authors like Oladejo and Oladipupo (2011) have attributed the cause of financial instability to a number of factors such as; inefficient financial management, corruption, unprofessionalism and dearth of adequate prudential guidelines. A review of body of literature as at the time of conducting this research revealed that no study had been performed to examine the possible role and influence of financial stability on economic performance in Nigeria. The experience in both crisis regimes essentially revealed two things. First, that macro-economic performance is vulnerable in the face of financial instability. Second, there seemed to be an untested connection between financial stability and economic growth in Nigeria. It is in the realization of this that this paper, embarks on this crucial research. This research paper aims to facilitate the work of the $\mathrm{CBN}$ in developing and promoting stability in the NFS so as to fashion the implementation of effective policies that would enhance sustained economic growth.

More so, in spite of the Macro-prudential policy later adopted by the apex bank, available data suggest that stability in the financial system in recent times maybe deteriorating. Traces of a looming crisis surfaced again as Capital Adequacy Ratio (CAR) dropped from 17.7\% in 2015 to $14.8 \%$ in the first half of 2016. In the same year, Asset Quality (AQ) of banks has deteriorated with Non-Performing Loans (NPLs) doubling from a year ago to $13.0 \%$ of total loans by end-2016, making Nigeria the weakest performer among her peers. Liquidity ratio has also decreased to $42.0 \%$ at end-June 2016, from $48.0 \%$ at end-2015 although still above the benchmark of $30.0 \%$. Profitability ratio has also been worsening with Return on Assets (ROA) 
reaching $12.6 \%$ and $1.5 \%$ in 2016 , driven by declining net interest margins. The indicator for earning and profitability showed unsustainability as expenditure items increased indicating declining profits (Ibrahim, Tamene, Tapsoba, \& Swiston, 2017).

Another puzzle however is the discrepancy in literature on the nexus between financial stability and economic growth. Whereas, Creel, Hubert and Labondance, (2013) cum Nasreen and Anwar (2017) conclude that financial stability has a positive and significant influence on economic growth. A plethora of researchers like Ogwumike et al (2008); Omolara et al(2016); Omoruyi et al (2014); Udom et al. (2018); Udude (2014); Ugwuanyi et al(2015) argue that not only is stability in the sector contentious, the stability reforms are yet to achieve significant contribution to sustainable economic growth in Nigeria. The study is therefore a contribution to the current argument and attempts to examine the existence or otherwise of a long-run relationship between financial system stability and economic growth, as well as the nature of influence or effect that exists between them. Section two is devoted to literature review, three discusses methodology, four presents and discusses results. While conclusion and policy recommendations are presented in section five.

\section{Literature Review}

Sere-Ejembi et al (2014) attempted to develop banking system stability index for Nigeria. The authors constructed a Banking System Stability Index (BSSI) for Nigeria using a selected set of statistical normalized FSI and macro-fundamentals from 2007-2012. The study posits that the index will serve to signal and warn financial regulators and authorities of potential vulnerability to the system. The study adopts the IMF-FSI's to form the framework for the construction of the BSSI and groups the indicators into three, namely: Banking Soundness Index (BSI), Banking Vulnerability Index (BVI) and Economic Climate Index (ECI). The resultant index captures the episodes of crises in the system over the study period and recommended the BSSI be used as an early mechanism of signaling fragility and as a complimentary method in detecting potential threat in the financial system and take preemptive measures in averting financial crisis. The authors adopted the weighted average method as their constructing mechanism. The resulting index serves as a measurement of the stability of the NFS. The financial sector comprises several other segments that wield influence in the system. Given that the banking industry is the dominant sector in the NFS owing to increase in financial technology and globalization, the systemic risks posed by other sectors in the system cannot be overlooked or ignored. As such, the BSSI may be inadequate to measure FSSI for Nigeria. 
Udom et al (2015) in their study on composing an index to support monetary and financial stability analysis in Nigeria, built a composite financial system stability index (FSSI) or a 'onestop-shop' stability indicator that warns and signals to a potential financial crisis in the NFS. The study achieves this by constructing a financial stability index from three categories of the financial system that includes the banking sector, the capital market and insurance sector. The study is basically an extension of Sere-Ejembi et al. (2014) that constructed a banking stability index for the NFS. The study aimed at constructing an FSSI using the weighted average method instead of a BSSI because the financial system comprises more than just the banking sector and argues that evaluating financial stability with only data for the banking sector may lead to bias and results that may prove misleading and inadequate. Considering that the IMF's core FSI are 12 in number, the study employs only the use of CAR as a gauge for bank stability. Given that the banking industry is considered as the most important sector in the financial system the use of only CAR may prove to be inadequate especially as other indicators for measuring banking stability are available.

Creel et al. (2013) in a paper on financial stability and economic performance investigated the nexus between both variables and expressed the pertinent need to include indicators for financial depth in evaluating financial stability. The data employed composed of $27 \mathrm{EU}$ member states as of 2011 and the duration spans from 1998-2011. The research adopts three different categories of indicators that serve as proxy for micro and macro elements of financial stability. They are; the Composite Indicator of Systemic Stress (CISS) provided by the ESCB, cumulative macro-prudential ratio for banks of each nation and indicators of financial stability index built with the aid of the Principal Component Analysis (PCA). The study discovers that financial stability has a significant and positive effect on all response variables selected for the study. Consequently, the study recommends the need for better micro and macro prudential regulation to prevent the worsening of bank's aggregate prudential ratios, which have adverse effect on economic growth.

Yusifzada et al (2015) in their study on financial intermediation and economic growth, employed a panel data covering 118 countries from 2004-2011 argued that none of the aspects of financial development adequately evaluates the complexity of the financial system alone as most researches do. The study goes further to construct a financial development index using the PCA from all four aspects of the financial system mentioned. With respect to financial stability, the study reveals that while financial stability is necessary for economic growth, however, an excessively high stability index although ensures a sound financial system triggers 
a reversal in economic growth because it results in underutilization of financial assets and resources in the economy.

Review of related studies reveals there is limited literature and empirical evidence on the nexus between the stability of the financial sector and economic growth in Nigeria. The spate of financial crisis in past decades like the Asian financial crisis of 1997 and global financial and economic crisis of 2007/2008 alerted the international financial community to bridge the chasm in literature and empirical evidence and unravel the untested connection between financial stability and economic growth. In Nigeria, only a handful of researches have dedicated interest to divulging the connection between financial stability and economic growth. Accordingly, this research is aimed at bridging this gap by adding to the few authors that have contributed to the literature in Nigeria.

Extensive empirical review of related literature reveals that, while several studies in Nigeria have constructed a composite financial stability index for the NFS, no study has shown its authenticity and predictability power by tracing or capturing past episodes of financial crisis from the SAP era to recent times. This research work aspires to fill this gap by using the PCA to construct an FSSI for Nigeria from 1986 to 2016 and plotting it on a line graph. The essence of this is to trace the historical trend of financial stability from the liberalization era to 2016, identify the specific periods of financial crisis, unearth the likely causes and proffer essential modifications towards forestalling future episodes of financial crisis in Nigeria. This study shows that this method is not only able to determine the current condition of the financial stability in Nigeria but also predict the likely occurrence of a financial crisis.

In addition, empirical review discovers an increasing number of authors on the international stage like Ahmed et al (2015); Batuo et al (2017); Creel et al. (2013), and Nasreen et al et (2017) have incorporated indicators of financial development into measures of financial stability in their research. They argue that several issues arise as a result of employing only indicators of financial stability in analyzing financial system crisis, chief of which is that the indicators do not accurately isolate the precise timing of the crisis as noted by Caprio et al (1999). They posit that the indicators of financial stability are backward looking and only come to bear when instability is severe enough to trigger a systemic crisis. This has necessitated the need for additional indicators alongside the FSI. Also, the four aspects of the financial system are interconnected and thus a study on one must incorporate one or more of the others so as to achieve superior results suitable for making predictions. This gap is yet to be filled on the 
Nigerian perspective. As such, this paper intends to fill this gap by incorporating two common statistics frequently used to represent financial depth, which are ratio of broad Money Supply relative to GDP (M2/GDP) and ratio of credit to private sector relative to GDP (CPS/GDP).

Furthermore, empirical research reveals that there is no consensus on an agreed method for constructing a composite financial system stability index. While several methods exist for constructing such an index from multiple variables, the choice of a method is contingent upon its empirical, statistical and predictability supremacy. Empirical review of this study reveals that Fadare (2011) is probably the first author to have attempted to construct a composite index of financial stability for the Nigerian economy. However, the research did not base its variables on macro-prudential analysis. None-the-less, its attempt is noteworthy; the study develops a predictive model of financial stability by applying the forward stepwise regression technique from 14 variables selected in the study. The second is Sere-Ejembi et al. (2014) that constructs a banking stability index and lastly, Udom et al (2015) constructed a Financial System Stability Index (FSSI) for Nigeria. Worthy of note is that none of these studies provided an analysis of the dynamic interaction between financial stability and economic growth in Nigeria; a gap this treatise aims to fill.

The studies of Sere-Ejembi et al. (2014); Udom et al (2015) centered on the macro-prudential analysis and utilized the weighted average method in constructing financial stability index. The limitation in employing the weighted average method arises from the likelihood that the constructed index will be influenced by the most dominant variable, thereby reducing the influence of other sub-sectors in evaluating stability of the financial system (Akosah, Loloh, Lawson, \& Kumah, 2018). This limitation bears grave consequences in its use particularly because of inability of the composite index to predict the occurrence of a looming crisis. A composite financial stability index that is based on the influence of a dominant variable while limiting the spillover effects of other sectors could prove to be misleading and inaccurate. A cardinal lesson learnt in the wake of the global financial crisis in 2007/2008 was that the nerve center of the crisis was the American (US) sub-prime mortgage sector. The US banking industry served as a transition mechanism into exacerbating the crisis that eventually snowballed into a global one (Ngwube et al,2014).

Alternatively, and in an attempt to avoid this limitation, this paper employs the use of Principal Component Analysis (PCA) in constructing a financial system stability index for Nigeria. Its use presents a different approach and an alternative method to constructing a financial system 
stability index for Nigeria. The PCA is essentially a dimension-reduction tool that can be utilized in condensing a large set of variables to a small set that still contains most of the information of the large set. PCA is a variance-focused approach, which seeks to achieve a linear combination of variables such that the maximum variance is extracted from the variables. It then removes this variance and seeks a second linear combination, which explains the maximum proportion of the remaining variables. In such a way, the resulting aggregate financial stability index will capture the influence of all the variables used in building the index, thus reflecting the interconnectedness of the sub-sectors in the financial system as it relates to stability (Brave \& Butters, 2011).

What is more? Extensive empirical research reveals that this study is probably the first in its use of PCA in constructing an FSSI for the NFS. However, its use in this study is justified by its use by a number of authors that have employed the PCA in constructing a financial stability index for their respective countries. Such authors are; Akosah et al. (2018) for Ghana; Arzamasov and Penikas (2014) for Isreal; Indrajit, Dipankar and Arti (2015) for India, and Mingione (2011) for Jamaica. In addition, the IMF employs the use of PCA in constructing an index for benchmarking financial systems around the world and in introducing a new broadbased index of financial development for 182 countries, including Nigeria (Svirydzenka, 2016).

\section{Constructing Financial System Stability Index (FSSI) for Nigeria}

The FSSI is computed using the Principal Component Analysis (PCA), which is one of the most frequently used multivariate data analysis. The PCA is chosen among other methods due to its tendency to reduce the dimensionality of a data set whilst retaining much of the variability in the data set. More so, the PCA overcomes multicollinearity issues that usually occurs when simultaneously introducing several financial variables that are highly correlated amongst each other (Brave \& Butters, 2011).

For the Banking Industry, the study employs the IMF's core FSI as a measure of stability in the money market. They are, Capital Adequacy Ratio (CAR), Asset Quality (AQ), Liquidity Ratio (LQR), Return on Asset (ROA) and Return on Equity (ROE) (International Monetary Fund, 2006). For the Capital market, the paper uses All Share Index (ASI), which measures the performance of companies listed on the Nigerian Stock Exchange. For the External sector, ratio of Money Supply to Foreign Reserve (MS/FR) was used. It measures the reserve adequacy of 
the financial system in the event of an external shock/vulnerability. In this study, the index comprises a fourth component, which is financial depth and is represented by two variables; Credit to private sector as a percentage of GDP (CPS/GDP) and M2 Broad Money Supply also as a percentage of GDP (M2/GDP). The justification for this inclusion is two-fold. First, it is crucial to understand that financial stability is but an aspect of financial development. Financial development incorporates financial inclusion/access, financial depth/size, financial efficiency/profitability and financial stability/soundness each important in its own right (Čihák, Demirgüç-Kunt, Feyen, \& Levine, 2012). Over the years, the evolution of financial systems has resulted in an interrelated and intertwined relationship between the dimensions of financial development. Thus, financial systems have become complex and multifaceted especially with the advent of globalization and improvement in technology. Consequently, the overlapping of these diverse components of financial development has become a regular feature of modern financial systems thus forming an inextricable network of siemese relationships. As such, a study on one aspect may also necessitate or involve a study of another (Creel et al., 2013). Secondly, authors like Batuo et al., (2017) and Caprio and Klingbiel (1999) argue that financial stability indicators (FSI) are mostly backward looking and do not capture accurately the precise timing of a financial crisis. As a result, this has necessitated the need for additional indicators alongside the FSI to correct this anomaly.

Hence, the expression can be given as;

$$
\begin{aligned}
& F S S I=[(C A R, A Q, L Q R, R O A, R O E)+A S I+M S / F R+(M 2 / G D P, C P S)] \\
& F S S I=B S+C M+E S+F D
\end{aligned}
$$

\subsection{Result of Principal Component Analysis (PCA)}

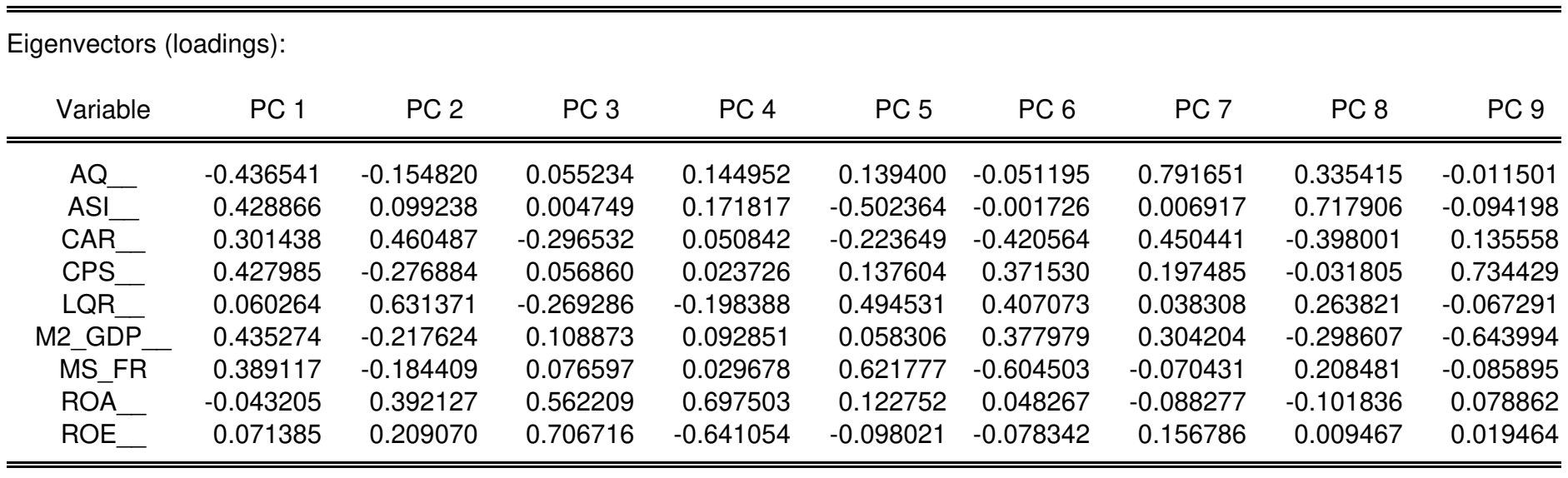


Furthermore, in this study, as opposed to employing the first three principal components as indicated by the scree plot, we go a step further by computing a single principal component from all other principal components. This allows the authors to generate a singular statistic representing the level of financial stability for the Nigerian Financial System.

\subsection{Result of Kaiser's Measure of Sampling Adequacy}

Following the results of the PCA, this research paper further tests the sampling adequacy of the nine variables selected for building the index (FSSI). This is achieved by employing the Kaiser-Meyer-Olkin (KMO) Measure of Sampling Adequacy. The KMO compares the partial correlations between variables and supports the relevance of employing the PCA on the selected variables used in constructing the index (Creel et al., 2013).

The KMO stipulates that a value closer to 1.0 imply that a PCA is useful with the data. Conversely, should the value fall below the benchmark of 0.50 , then the result of the PCA is not useful with the data (Bozovic \& Smolovic, 2016).

\begin{tabular}{|c|c|}
\hline & MSA \\
\hline $\begin{array}{l}\mathrm{AQ} \\
\mathrm{ASI}\end{array}$ & $\begin{array}{l}0.863182 \\
0.770960\end{array}$ \\
\hline CAR & 0.627230 \\
\hline CPS & 0.693701 \\
\hline LQR & 0.433204 \\
\hline M2_GDP & 0.759000 \\
\hline MS_FR & 0.875329 \\
\hline $\mathrm{ROA}$ & 0.304918 \\
\hline ROE & 0.452064 \\
\hline Kaiser's MSA & 0.721690 \\
\hline
\end{tabular}

In this study, however, the KMO result reveals a value of this statistic that is equal to 0.7 , which is satisfactory.

HISTORICAL TREND OF FSSI IN NIGERIA (1986 to 2016) 


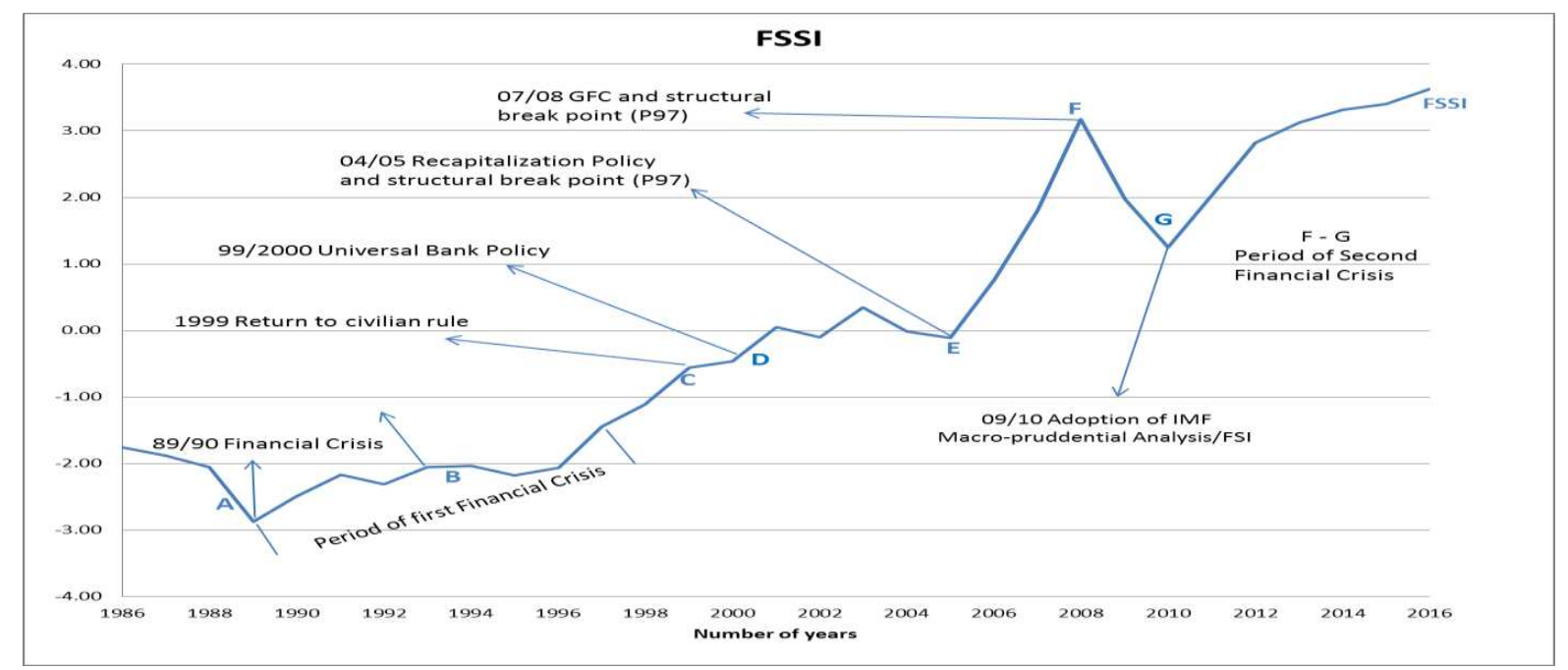

Source: Authors computation using Microsoft 2010.

The graph above represents the trend of financial system stability as measured by FSSI and generated by PCA from 1986 to 2016. From the graph, it becomes possible to identify, visualize and understand the effect of past socio-political and economic events on financial stability in Nigeria for the duration of the study. As labelled, the authors have matched several important points along FSSI and the associating historical event that may have led to its shaping. Furthermore, since the study approaches the literature from the stability standpoint in lieu of instability, thus, the higher the FSSI, we assume the more stable is the financial system.

Beginning from point A, which captures the start of the 1989 financial crisis reveal that financial stability was at its lowest at $-2.87 \%$. The 1989/1990 financial crisis heralded the failure and subsequent bankruptcy of a myriad of commercial banks that lasted until 1996/1997 (Ogujiuba \& Obiechina, 2011). More importantly, several authors like Olukotun, James and Olorunfemi (2013) assert that a banking boom ensued after SAP policy; however, the trend in FSSI showed that as at 1986, FSSI was $-1.76 \%$ and continued on a downward trend until 1989 , indicating that the SAP policy had a negative effect on stability. The FSSI shows that stability began improving from 1990 although its values were still in the negative up until 2001. This is despite the tumultuous era of bank failures that occurred between 1989 to 1998 (Adeyemi, $2011 \&$ Ochei, 2012). This phenomenon has been explained by ---- in his work where his study reveals that the closure of banks during a crisis period may not be necessarily bad for the financial system, as the banks that survive the crisis become stronger with a larger capital base. In addition, to stem the tide of failing banks, the period witnessed a number of prudential policy reviews for new entrants into the industry by the Central Bank of Nigeria. The CBN increased the capital adequacy ratio no less than four times between 1988 and 1998 (Ochei, 2012). Points 
B, C, D and E seem to have positive effects on FSSI as its trend continues to increase up until 2005 .

The FSSI also captures the effect of the 2004/2005 bank recapitalization policy on financial stability indicated by point $\mathrm{C}$. The authors observe that financial stability improved greatly after the Recapitalization policies even as the number of banks reduced. The policy further increased capital requirements of banks from N2 billion to N25 billion Naira and caused a shock/break (indicated by Perron 97-unit root test) in the FSSI data series where it rose from $0.11 \%$ in 2005 to $3.17 \%$ in 2008 . Hence, this papers agree with the assertion of other works like Ogege, Williams and Emerah (2012) that the 2004/05 Recapitalization policy was a profound success. The rise of financial stability was however, truncated by the outbreak of the Global Financial Crisis (GFC) in 2008 and saw it plummet to $1.25 \%$ in 2010. The adoption of the Macro-prudential policy in 2010 saw stability increase to the highest in its three-decade history at $3.63 \%$ in 2006 .

\section{Methodology}

The study relies on analysis of time series (secondary) data spanning the period 1986-2016, as such, the study adopts an exploratory design meant to examine the relationship between financial system stability and economic growth in Nigeria. However, since time series data are characterized by random walk (Gujarati \& Porter, 2009), the dataset was subjected to two-unit root tests (Perron 97 \& Lee Strazicich 2001) that allows for the presence of unknown structural breaks in the data series. The primary objective of the test is to convert time series to a stationary process in order to prevent misleading results. Perron's 1997 unit root test is selected because its testing power is almost similar to that of Zivot Andrew's model, although that of Perron is considered to be more comprehensive (Shrestha \& Chowdhury, 2005). Lee and Strazicich (2001) is selected because it accommodates for the presence of two structural breaks, the others only account for one. In this paper, both unit root tests must agree on the stationarity of the variables to ascertain stationarity and their results are pitted against other conventional unit root tests (ADF and PP) to show the difference in the results. The unit root model for Perron ' 97 is given below;

$Y_{t}=\mu+\theta D U_{t}+\beta t+Y D T_{t}+\delta D\left(T_{b}\right)_{t}+\alpha y_{t-1}+\sum_{i=1}^{k} C i \Delta y_{t-I}+e_{t}$

Where $Y$ is the variable under consideration, $\mu$ is the intercept or constant, $\Delta$ is the first difference operator, $t$ is the time trend, $D T_{b}$ is the time at which structural change occurs, $D T$ 
is the slope and $e$ is the error term. The model allows for only one time change in both intercept and slope.

The unit root model for Lee Strazicich is expressed thus;

$\Delta y_{t} \delta^{\prime} \Delta Z_{t}+\emptyset \hat{S}_{t-1}+\sum_{i=1}^{k} y_{i} \Delta \hat{S}_{t-I}+\mu$

Where $Y$ is the variable under consideration, $\Delta$ is the first difference operator, $t$ is the time trend and $\mu$ is the error term. The pair-wise granger causality test was thereafter conducted, and result shows a uni-directional causality. This result fundamentally reveals that the model under consideration is a system equation. To this end, Johansen and Joselius (1988) system cointegration test is conducted to ascertain whether the series revert to their long-run mean value. The estimated causality and co-integration equations are as shown in equations 3 and 4 below;

$y_{t}=a_{1}+\sum_{i=1}^{n} \beta_{i} x_{t-i}+\sum_{j=1}^{m} \gamma_{j} y_{t-j}+e_{1 t}$

$x_{t}=a_{2}+\sum_{i=1}^{n} \theta_{i} x_{t-i}+\sum_{j=1}^{m} \delta_{j} y_{t-j}+e_{2 t}$

$\Delta \mathrm{X}_{\mathrm{t}}=\mu+\sum_{i=1}^{p-1} \Gamma \mathrm{i} \Delta \mathrm{X}_{\mathrm{t}-1}+\Pi \mathrm{X}_{\mathrm{t}-1}+\varepsilon_{\mathrm{t}}$

However, in achieving the overall goal of the study, which is to evaluate the influence of financial system stability on economic growth in Nigeria, the Vector Error Correction Model (VECM) is presented thus;

$\Delta Y=\beta_{0}+\sum_{i=1}^{k-1} Y_{i} \Delta Y_{t-I}+\sum_{j=n}^{k-1} \delta \Delta X_{t-j}+\sum_{m=i}^{k-1} \varepsilon_{m} \Delta R_{t-m}-\lambda \mathrm{ECT}_{\mathrm{t}-1}+\mu_{\mathrm{it}}$

The expression of the VECM enables the analysis of both the long-run and short-run dynamics of the data series. The VECM basically expresses the change in $\mathrm{Y}$ to be a function of not only the past changes in $\mathrm{Y}$ but also the current and previous changes in X, R.... All variables in the model are considered as endogenous. More significantly is that VECM specifies the ECT which is actually the variable of the lagged OLS residual from the long-run co-integrating equation specified as;

$Y_{t}=\beta_{0}+\beta_{1} X_{1}+\varepsilon_{t}$ 
$\mathrm{ECT}_{\mathrm{t}-1}=Y_{t-1}-\beta_{0}-\beta_{1} X_{t-1}-\beta_{2} X_{t-1}-\beta_{3} X_{t-1}+\beta_{4} X_{t-1}$

The ECT, which is also referred to as the co-integrating equation relates to the fact that the last period deviation from the long-run equilibrium (the error) affects the short-run dynamics of the dependent variable Y. In this study, the goal is to establish or determine the last deviation of GDP $_{\text {gr }}$ from the long-run equilibrium (the error) as influenced by changes in GDP, FSSI, INFR, INTR, NEXR, GCF and also ascertain the coefficient of the ECT, $\lambda$, which expresses the speed of adjustment at which GDP returns to equilibrium.

The VECM model is expressed below;

$\Delta \boldsymbol{G D P} \boldsymbol{P}_{t}=\eta+\sum_{i=1}^{k-1} \beta_{i} \Delta \boldsymbol{G D P} \boldsymbol{P}_{t-i}+\sum_{j=1}^{k-1} \theta_{j} \Delta \operatorname{FSSI}_{t-j}+\sum_{m=1}^{k-1} \vartheta_{m} \Delta I N F R_{t-m}+\sum_{n=1}^{k-1} \pi_{n} \Delta I N T R_{t-n}+$ $\sum_{v=1}^{k-1} \rho_{v} \Delta G C F_{t-v}+\sum_{g=1}^{k-1} \sigma_{g} \Delta N E X R_{t-g}+\lambda 1 E C T_{t-1}+\mu_{1 t}$

Where, GDPgr = Growth rate of Gross Domestic Product, measured in N'Billion; FSSI = Financial System Stability Index (A composite of indicators covering money market, financial markets, external sector, and financial depth); INFR = Inflation rate, measured in percentage; INTR = Interest rate, measured in percentage; GCF = Gross Capital Formation, measured as percentage of GDP; NEXR = Nominal exchange rate, measured as ratio of dollar to naira; ECT = Error Correction Term; $\lambda=$ Lambda measuring dynamic speed of adjustment; $\mu=$ Stochastic variable.

\section{Results and Discussions}

\subsection{Unit Root Results}

This paper presents the results of both unit root tests (with and without structural breaks). It further argues that it is imperative this is performed considering the NFS experienced crisis in 1989/1990 and in 2007/2008 GFC was witnessed and as such, not accounting for structural breaks may result in spurious results. These results are presented below;

Table 1. Unit Root Test Without Structural Breaks

\begin{tabular}{lllll}
\hline & ADF & & PP & \\
\hline FSSI & $\mathrm{t}-$ Stat & Decision & $\mathrm{t}$-Stat & Decision \\
& -3.986 & $\mathrm{I}(0)$ & -4.224 & $\mathrm{I}(0)$ \\
GDP & $(-3.574)^{* *}$ & & $(-3.568)^{* *}$ & \\
& -3.705 & $\mathrm{I}(0)$ & -3.653 & $\mathrm{I}(0)$ \\
INTR & $(-3.670)^{*}$ & & $(-2.963)^{* *}$ & \\
& -5.819 & $\mathrm{I}(0)$ & -5.729 & $\mathrm{I}(0)$ \\
& $(-4.374)^{*}$ & & $(-4.296)^{*}$ & \\
\hline
\end{tabular}




\begin{tabular}{lllll}
\hline INFR & -4.169 & $\mathrm{I}(0)$ & -3.162 & Unit root \\
& $(-3.752)^{*}$ & & $(-4.296)$ & \\
NEXR & -2.892 & Unit root & -2.989 & Unit root \\
& $(-4.296)$ & & $(-4.296)$ & \\
GCF & -1.712 & Unit root & -2.086 & Unit root \\
& $(-3.670)$ & & $(-4.296)$ & \\
\hline
\end{tabular}

Note: $* * *=10 \%, * *=5 \%, *-1 \%$. Critical values $=()$

Table 2. Unit Root with Structural Breaks

\begin{tabular}{|c|c|c|c|c|c|c|}
\hline Variables & $\begin{array}{l}\text { Perron'97 } \\
\text { t-Stat }\end{array}$ & Break Point & Decision & $\begin{array}{l}\text { Lee \& Strazidch } \\
\text { t-Stat }\end{array}$ & Break Point & Decision \\
\hline FSSI & $\begin{array}{l}-6.067 \\
(-5.59) * *\end{array}$ & 2008 & $\mathrm{I}(1)$ & $\begin{array}{l}-9.07 \\
(-6.821)^{*}\end{array}$ & $02 / 06$ & $\mathrm{I}(1)$ \\
\hline GDP & $\begin{array}{l}-11.628 \\
(-6.32) *\end{array}$ & 1993 & $\mathrm{I}(1)$ & $\begin{array}{l}-7.903 \\
(-6.750)^{*}\end{array}$ & $96 / 2001$ & $\mathrm{I}(1)$ \\
\hline INTR & $\begin{array}{l}-10.547 \\
(-6.32)^{*}\end{array}$ & 1991 & $\mathrm{I}(1)$ & $\begin{array}{l}-10.207 \\
(-6.932)^{*}\end{array}$ & $96 / 06$ & $\mathrm{I}(1)$ \\
\hline INFR & $\begin{array}{l}-10.813 \\
(-6.32)^{*}\end{array}$ & 1996 & $\mathrm{I}(1)$ & $\begin{array}{l}-9.884 \\
(-6.691)^{*}\end{array}$ & $96 / 10$ & $\mathrm{I}(1)$ \\
\hline NEXR & $\begin{array}{l}-6.449 \\
(-6.32)^{* * *}\end{array}$ & 2004 & $\mathrm{I}(1)$ & $\begin{array}{l}-6.450 \\
(-6.175)^{* *}\end{array}$ & 97/06 & $\mathrm{I}(1)$ \\
\hline GCF & $\begin{array}{l}-6.449 \\
(-6.32)^{*}\end{array}$ & 2004 & $\mathrm{I}(1)$ & $\begin{array}{l}-6.45 \\
(-6.175)^{* *}\end{array}$ & 97/06 & $\mathrm{I}(1)$ \\
\hline
\end{tabular}

Note: $* * *=10 \%, * *=5 \%, *-1 \%$. Critical values $=(\mathrm{)}$

From Table 1 above, the unit root test results of ADF and PP agree on the stationarity of three out of the six variables selected for the study and differ on three. Table 2 which presents the unit root test results that allows for structural breaks is in vast contrast with that of Table 1 . The unit root test results of P97 and LS agree on the stationarity of all the series after first differencing

As obtainable in the ground breaking seminar work of Pierre Perron (1989) and observed, comparing the unit root test results in Table 1 and 2 above; with an aim of avoiding spurious results, this paper considers the unit root test results with structural breaks at levels (Appendix I), as well as that presented in Table 1 to be inaccurate. Accordingly, to achieve stationarity, the first difference of all the variables under review (Table 2) is attained, coupled with the Pairwise Granger Causality result (which shows a bi-directional causality - Appendix II) and thus informs the basis for the Johansen System co-integration test which result is presented below. 
However, the lag length criterion is based on AIC which specifies an optimal lag length of two (2) for the model. The decision is based on the rule of thumb which opts for the most dominant lag length by the various criterions (See VAR Lag Order Selection Criteria in Appendix III).

\subsection{Johansen System Co-integration Test}

Table 3a. Unrestricted Cointegration Rank Test (Trace)

\begin{tabular}{ccccc}
\hline \hline $\begin{array}{c}\text { Hypothesized } \\
\text { No. of CE }(\mathrm{s})\end{array}$ & Eigenvalue & $\begin{array}{c}\text { Trace } \\
\text { Statistic }\end{array}$ & $\begin{array}{c}0.05 \\
\text { Critical Value }\end{array}$ & Prob.** \\
\hline \hline None $*$ & 0.928495 & 165.9485 & 95.75366 & 0.0000 \\
At most $1 *$ & 0.754145 & 92.08497 & 69.81889 & 0.0003 \\
At most 2* & 0.682415 & 52.80065 & 47.85613 & 0.0160 \\
At most 3 & 0.343713 & 20.68439 & 29.79707 & 0.3776 \\
At most 4 & 0.249592 & 8.891976 & 15.49471 & 0.3755 \\
At most 5 & 0.029974 & 0.852098 & 3.841466 & 0.3560 \\
\hline \hline
\end{tabular}

Table 3b. Unrestricted Cointegration Rank Test (Maximum Eigenvalue)

\begin{tabular}{ccccc}
\hline \hline $\begin{array}{c}\text { Hypothesized } \\
\text { No. of CE }(\mathrm{s})\end{array}$ & Eigenvalue & $\begin{array}{c}\text { Max-Eigen } \\
\text { Statistic }\end{array}$ & $\begin{array}{c}0.05 \\
\text { Critical Value }\end{array}$ & Prob.** \\
\hline \hline None $*$ & 0.928495 & 73.86354 & 40.07757 & 0.0000 \\
At most $1 *$ & 0.754145 & 39.28432 & 33.87687 & 0.0103 \\
At most 2* & 0.682415 & 32.11627 & 27.58434 & 0.0122 \\
At most 3 & 0.343713 & 11.79241 & 21.13162 & 0.5683 \\
At most 4 & 0.249592 & 8.039878 & 14.26460 & 0.3747 \\
At most 5 & 0.029974 & 0.852098 & 3.841466 & 0.3560 \\
\hline \hline
\end{tabular}

The Trace and Maximum Eigenvalue test results disclose that the null hypothesis, which specifies no long-run co-integration among any of the variables under investigation can be rejected and the alternative hypothesis identifying the presence of co-integration among the variables is accepted. This is because, the trace statistic and Maximum Eigenvalue test value reveal three co-integrating equations among the variables. The null hypothesis specifying no co-integration at none and at most 1, 2, of the variables can be rejected as their respective p-values are significant at $5 \%$ level of significance.

\subsection{Vector Error Correction Model (VECM)}

They are basically two results to consider, the co-integrating equation/Error Correction Term (ECT) (long-run model) and the ECM (short-run model). In this study, we shall first present the results of the Co-integrating Long-run equation and then the ECM short-run dynamic.

The results from the co-integrating equation/ECT can be re-written as;

$$
\mathrm{ECT}_{\mathrm{t}-1}=1.000 G D P_{t-1}+0.516 F S S I_{\mathrm{t}-1}+0.225 \mathrm{GCF}_{\mathrm{t}-1}+0.008 I_{N F R} R_{\mathrm{t}-1}-0.500 I_{N T R} \mathrm{t}-1-
$$




$$
0.087 N E X R_{\mathrm{t}-1}+7.183
$$

The above co-integrating equation (long-run equation) can be interpreted thus; In the long-run, financial stability (FSSI), gross capital formation (GCF) and inflation rate (INFR) have negative impact on economic growth rate $\left(\mathrm{GDP}_{\mathrm{gr}}\right)$ ceteris paribus. Contrarily, in the long-run, interest rate (INTR) and nominal exchange rate (NEXR) have positive impact on economic growth rate ceteris paribus.

The second aspect of the result presents the short-run relationship among the variables. The results are contained in Table 4 below.

Table 4. Short-Run Relationship

\begin{tabular}{lcllllll}
\hline Variables & $\lambda$ & $\Delta \mathrm{GDP}_{\mathrm{t}-1}$ & $\Delta \mathrm{FSSI}_{\mathrm{t}-1}$ & $\Delta \mathrm{GCF}_{\mathrm{t}-1}$ & $\Delta \mathrm{INFR}_{\mathrm{t}-}$ & $\Delta \mathrm{INTR}_{\mathrm{t}-1}$ & $\Delta \mathrm{NEXR}_{\mathrm{t}-}$ \\
& & & & & 1 & \\
\hline Co-efficient & $-1.0730 * * *$ & 0.0637 & -0.6935 & 0.2497 & 0.0471 & -0.0174 & -0.1007 \\
& $(0.2706)$ & $(0.1804)$ & $(1.4471)$ & $(0.4039)$ & $(0.048)$ & $(0.189)$ & $(0.0527)$ \\
& & & & & & \\
Observations & 29 after adjustments & & & & & \\
R-Squared & 0.64 & & & & & & \\
F-Stat & 5.499 & & & & & & \\
Prob (F-Stat) & 0.001 & & & & & & \\
\hline
\end{tabular}

Source: Authors compilation using E-views 9

$\Delta \boldsymbol{G D P}_{\mathrm{t}}=0.588+0.063 \boldsymbol{G D P}_{t-1}-0.693 F S S I_{t-1}+0.249 G C F \% G D P+0.047 I_{N F R_{t-1}}-0.017 I_{N T R_{t-1}}-0.100 N E X R_{t-}$ $1-1.07 E C T_{t-1}$

The coefficient of $\mathrm{GDP}_{\mathrm{t}-1}(+0.063)$ suggests that a unit change in GDP is related with a 0.063 increase on itself on average, ceteris paribus in the short run. The p-value of GDP $(0.727)$ is greater than 5\% level of significance and imply that GDP does not have a significant influence on itself in the short-run.

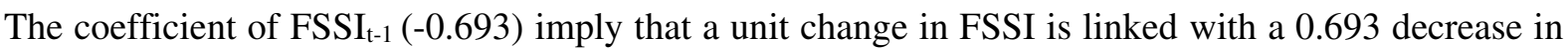
GDP on average, ceteris paribus in the short run. The p-value of FSSI (0.636) is greater than $5 \%$ level of significance and imply that FSSI does not have a significant influence on GDP in the short-run. The coefficient of $\mathrm{GCF}_{\mathrm{t}-1}(+0.249)$ imply that a unit change in GCF is connected with a 0.249 increase in GDP on average, ceteris paribus in the short run. The p-value of GCF $(0.543)$ is greater than $5 \%$ level of significance and proposes that GCF does not have a significant influence on GDP in the short-run. The coefficient of $\operatorname{INFR}_{\mathrm{t}-1}(+0.047)$ implies a unit change in INFR is linked with a 0.047 increase in GDP on average, ceteris paribus in the short-run. Its associated p-value (0.339) is more than $5 \%$ level and suggests it does not have a significant influence on GDP in the short-run. The coefficient of INTR $\mathrm{t}_{\mathrm{t}}$ ${ }_{1}(-0.017)$ implies that a unit change in INTR is connected with a 0.017 decrease in GDP on average, ceteris paribus in the short-run. Its corresponding p-value (0.927) is greater than the 5\% level submits that it does not have a significant effect on GDP in the short-run. The coefficient of $\operatorname{NEXR}_{t-1}(-0.100)$ implies that a unit change in NEXR is correlated with a 0.100 decrease in GDP on average, ceteris paribus in the short-run. With a p-value of 0.069 , which is more than $5 \%$ level reveals its influence on 
GDP in the short-run is insignificant but significant at $10 \%$ level. The results also reveal that none of the variables under investigation bear short-run causal effects with each other.

The coefficient of $\mathrm{ECT}_{\mathrm{t}-1}(-1.07)$ signifies that the previous period's deviation of GDP from the longrun equilibrium is corrected at an adjustment speed of $107.0 \%$ in the current period in the long-run. Its associating p-value of 0.0007 , which is less than the $1 \%$ level of significance, divulges that it is statistically significant. More importantly, the coefficient of the ECT $(\lambda)$ agrees with the Johannsen cointegration results, which specifies long-run relationship among the variables under review. The longrun causal effect is determined through the t-statistics of the error correction term, which is significant at 0.0007 . In addition, the R-Squared statistic for the model is $64.0 \%$, indicating the strength of the model and underpins the significance of the independent variables and their lagged effect in explaining the changes in GDP in the short-run. The probability value of the F-statistics is 0.001 , indicating that the entire model is statistically significant at $1 \%$ and the Durbin-Watson value of 1.89 is close 2 suggesting that the model is significant.

However, the negative coefficient of financial stability index suggests that it bears an inverse relationship with economic growth. This result differs with the considerable number of empirical studies which emphasize financial stability should have a positive and significant influence on economic growth. However, the results of this study agrees with the conclusions of Dhal et al. (2011); Gambacorta (2011); Locarno (2011) and Yusifzada and Mammadova (2015) that find that an excessively high financial stability which has surpassed the threshold where stability stimulates economic growth only results in reversal of economic growth. These studies conclude that as a consequence of the global financial crisis in 2007/2008, the adoption of the Basel III bank regulatory requirements which form part of the IMF's core set prudential indicators has been associated with higher risk aversion and more stringent capital requirements to ensure the stability of financial systems. These studies assert that every percentage increase in capital adequacy and liquidity ratio can be associated with the steady decline in economic growth (Dhal et al., 2011). The Macroeconomic Assessment Group (MAG) of the Basel Committee on banking supervision has corroborated the results and conclusions of these studies which estimated the transition costs of the new Basel III regulatory standards in terms of loss in GDP growth. The group's findings reported a negative impact of capital adequacy ratio on economic growth.

Dhal et al. (2011) and Yusifzada and Mammadova (2015) further showed an S-shaped inverted function between financial stability and economic growth in developed and developing economies. They discovered that most developing economies have the best performance of 
financial stability index. In these countries, the connection between financial stability and economic growth is positive but only up to some point. However, further excessive increase in financial stability move their economies to the negative slope tail of the function where economic growth begins to fall. In other words, lower economic growth is sacrificed for higher financial stability. On the other hand, the financial stability index for developed economies is much lower compared to developing economies. The financial stability index for developed economies reaches a threshold for sustaining economic growth.

Furthermore, Yusifzada and Mammadova (2015) finds developed economies like England and Japan to be leading in the aspects of depth, access and efficiency but poor in stability while developing economies like Nigeria to be leading in the aspect of stability but poor in the aspects of depth, inclusion and efficiency. On one hand, the global financial crisis showed that financial stability is vital for economic growth. Conversely, excessive increase in financial stability index, which improves stability can hinder economic growth. In this scenario, the study discovers that higher stability index might not only ensure stability but be a sign of asset underutilization.

This study discovers that the FSSI for Nigeria is stable, this stability is necessary to stimulate economic growth especially after financial reforms. However, financial stability is not sufficient to sustain economic growth in Nigeria. This is because, the Nigerian financial regulators have focused excessively on only the aspect of stability while paying less attention to other equally important aspects of financial development. The ability of the financial sector to sustain economic growth does not only depend on stability but also on other aspects of financial development like depth, inclusion and efficiency. Financial depth ensures the ability of the individuals and firms to access financial credit from financial institutions. This study finds the average CPS/GDP for developed economies like England and Japan for the duration of this study to be 3.20 and 6.15 respectively, while that of developing economies like Nigeria and Rwanda to be 0.45 and 0.19 (Svirydzenka, 2016). The CPS/GDP of developed economies increased by $32.0 \%$ points over the past 8 years and are ahead in economic growth rates, while that of developing economies like Nigeria have declined from 12.0 to $10.0 \%$ points within the same timeline and are lagging behind in economic growth rates (Yusifzada \& Mammadova, 2015).

Financial inclusion ensures more of the Nigerian population is captured within the financial system. Financial efficiency ensures the payment system is lucrative to all economic agents in 
the system. The collective synergy of all four aspects guarantees the optimum utilization of financial resources by economic agents in the economy and thus sustains economic growth. This brings about increased incomes, employment, increased economic activity, reduction of inequality and poverty (Levine, Loayza, \& Beck, 2000).

Conversely, a graphical analogy (See Appendix IV) of financial system stability as measured by FSSI and economic growth rate is plotted to show the relationship between both variables, and to further buttress and corroborate the findings of Johansen cointegration result and VECM. The graph gives a visual appeal of the historical trend of FSSI and GDP gr $_{\text {from }} 1986$ to 2016 in the NFS and displays the structural break point dates as indicated by the unit root tests of Perron 97 and Lee Strazicich. It also highlights some of the likely social, political and economic phenomenon that may have influenced it. The graph reveals the boom-burst cycle as it occurs after major economic/financial policies were initiated. More importantly, the graph shows the reaction of both variables leaving the study to make logical conclusions.

The graph clearly captures prominent events in the past like the 1989/1990 financial crisis labelled as point $\mathrm{K}$, the 2007/2008 global financial crisis labelled as point $\mathrm{G}$ and the 2014 drop in global price of oil labelled as point J. The graph shows clearly that the PCA can be used in constructing the FSSI for Nigeria. More importantly, the FSSI can be used as a measure of financial stability and as a warning mechanism for financial authorities in predicting the likely onset of financial crisis as indicated in points $\mathrm{K}$ and $\mathrm{G}$. As economic growth is shown on points A and F, FSSI was already falling at points $\mathrm{K}$ and G, which eventually culminated in the fall of economic growth some years later on points B and I. This trend in both variables as shown in the graph may offer an explanation to the boom-burst cycle that has plagued the Nigerian economy after the liberalization policy of 1986 and recapitalization policy of 2005 . The financial policies in 1986 and 2005 were effective in stimulating economic growth initially but not sufficient to sustain it. The graph also shows that the prudential policies adopted by the CBN in 1989 and adoption of macro-prudential policy in 2009/2010 were effective in the recovery of FSSI as labelled on point $\mathrm{H}$ and $\mathrm{K}$. In addition, the trends in both variables seem to corroborate the results of long-run co-integration. At points $\mathrm{B}$ and $\mathrm{K}$ where both variables are farthest apart, they co-integrate at point $\mathrm{C}$ and $\mathrm{D}$.

As indicated by the graph, FSSI is higher than it was in the past, suggesting that it is more stable. Hence, the study corroborates the assertion of the CBN that the NFS is more stable than it was in the past (CBN, 2016; Umoru \& Osemwegie, 2016). However, as the VECM results 
reveal, FSSI is not significant enough to engender economic growth in Nigeria and such findings agree with submissions of other authors like Yusifzada and Mammadova (2015) that higher financial stability results in asset underutilization and leads to a slowdown in economic growth. This study submits that the likely reason for this is that the FSSI is so high that it has caused the hoarding and underutilization of financial assets. As a result, economic agents are unable to access the required financial services for economic activities in Nigeria. Because of the low level of some components of the index like CPS/GDP, the NFS is incapable of influencing economic growth in Nigeria. This research paper advances the argument that the incapability of the financial system to perform its role of reallocating funds from the financial system to productive sectors of the economy impedes manufacturing and establishment of industries (Omolara \& John, 2016). This is evidenced by the mono-cultural nature of the economy, high unemployment rate, bloated government sector, crime, high importation, which are clear signs that the private sector in Nigeria is moribund and a result of the low level of CPS.

\subsection{Diagnostic Tests}

The Breusch-Godfrey serial correlation LM test shows that there is no serial correlation in the result estimate. This is because the p-values are greater than the 5 per cent level of significance and thus, the null hypothesis is rejected. See Appendix V. Similarly, the Breusch-PaganGodfrey Heteroskedasticity test was conducted, and the result also reveals that the p-values of Chi-Square are greater than 5\% level of significance. This result indicates that the null hypothesis cannot be rejected and hence there is no heteroscedasticity in the model. See Appendix VI.

Normality test was conducted to evaluate the nature of data distribution of the model. The result as presented in Appendix VII shows the value of the skewness (-0.106) and implies that the model is moderately skewed and mirrors that of a normal distribution. The value of the kurtosis result of 2.937 suggests that the data is platykurtic in nature. The probability value of the Jarque-Berra statistic of 0.97 indicates that the data distribution of the model is normally distributed, this is because the p-value of JB is greater than the $5 \%$ level, indicating a normal distribution.

However, stability test (otherwise called CUSUM test) was also conducted to ascertain the dynamic stability of the model. The guiding principle of the CUSUM test stipulates that insofar as the blue line equation of the model falls in between the red lines, the model is said to be 
dynamically stable. As can be viewed from Appendix VIII, the blue equation line lies in between the red lines indicating that the model is dynamically stable.

\subsection{Variance Decomposition}

The variance decomposition of the forecast error gives the percentage of unexpected variation in each variable (the dependent variable) that is produced by shocks from other variables (the independent variables). It indicates the relative impact one variable has on another. Employing the variance decomposition, this paper attempts a five-year forecast of the significant impact emanating from the shock the selected variables have on the dependent variable. Appendix IX presents the results of the variance decomposition of financial stability on economic growth in Nigeria and the interpretations. Furthermore, it must be mentioned that only the forecast error variance decomposition in economic growth rate $\left(\mathrm{GDP}_{\mathrm{gr}}\right)$ will be considered. The reason for this is two-fold. First, the percentage forecast error variance decomposition in economic growth rate fulfills the primary objective of this research paper. Second, only the co-integrating equation (speed of adjustment) of economic growth rate $\left(\mathrm{GDP}_{\mathrm{gr}}\right)$ conforms to economic apriori expectations. The others are not statistically significant.

The figures in Appendix IX reveal the percentage of forecast error variance in economic growth rate $\left(\mathrm{GDP}_{\mathrm{gr}}\right)$. In period $1, \mathrm{GDP}_{\mathrm{gr}}$ divulges strong endogenous relationship (implying strong influence on itself). In the short run, the GDPgr itself explains $100.0 \%$ of forecast error variance in GDPgr. However, as in the long run the shock/impact of GDPgr on itself dwindles, falling from $100.0 \%$ in the first period to $54.48 \%$ in the fifth period.

On the other hand, FSSI, GCF, INFR and NEXR exhibit strong exogenous relationship (implying weak influence) on GDPgr. This suggests that, in the long-run, ceteris paribus, the shock or impact of financial stability, gross capital formation, inflation rate and nominal exchange rate will exert minimal influence on Nigeria's economic growth. This result is in tandem with the VECM results, which suggests that none of the independent variables mentioned above have a significant influence/effect on $\mathrm{GDP}_{\mathrm{gr}}$ in the short run. While the percentage of forecast error variance in $\mathrm{GDP}_{\mathrm{gr}}$ caused by the shocks in the variables mentioned above increases, the increases are infinitesimal in the long run.

However, INTR has a strong exogenous relationship with GDPgr in the short run (period 1). This agrees with the result of the VECM that shows an insignificant influence/effect on GDPgr. 
Unlike the other variables, in the long-run, ceteris paribus, its percentage forecast error variance in $\mathrm{GDP}_{\mathrm{gr}}$ continues to increase thereby suggesting a strong exogenous relationship (implying strong influence) on GDPgr leading up to period 5 rising from 10.94 in the first period to 23.69 in the fifth period.

\section{Conclusions and Policy Recommendations}

The paper concludes that financial stability is not significant in influencing economic growth in Nigeria and all things being equal even five years into the future. This submission hinges on overindulgence in the micro/macro prudential measures by the country's apex bank and as such denies the private sector access to sufficient financial resources. This however comes with negative multiplier effect in the form of low economic activities, employment and income reduction, and thus reduces economic growth. The study therefore recommends the following; Firstly, the Apex bank should implement FSSI as a complimentary test to be used alongside the stress tests in predicting and ensuring a stable financial system and as such, be a recurrent feature in her Financial Stability Reports. While the stress tests x-ray the performance of the different sectors in the financial system, the FSSI x-rays the performance of the entire financial system. Secondly, indicators for financial depth be included as part of the indicators for financial stability. This mirrors the interconnectedness and complexity of what the financial system has become today due to technology and globalization. Thirdly, the federal government through financial authorities must give attention to other aspects of financial development like depth, inclusion and efficiency as opposed to stability alone in ensuring sustainable economic

growth in Nigeria. Financial stability is necessary to stimulate economic growth but by itself is not sufficient to sustain that growth, as higher stability index leads to underutilization of financial assets and reversal in economic growth.

Furthermore, the Central Bank of Nigeria shelve its proposed increase of capital adequacy ratio from $10.79 \%$ to $15.26 \%$ in the second quarter of 2019 . This recommendation comes in light of the empirical results obtained in this study, which reveals that an increase in CAR, which is a vital component of the FSSI will invariably result in its increase. Financial stability is at an alltime high of $3.63 \%$ in 2016 , while economic growth is $-1.6 \%$ in the same year. As revealed in the results, despite the increase in CAR, economic growth continues to under-perform as both variables proceed in opposite directions. In addition, the impact of FSSI on economic growth in Nigeria is insignificant and negative. Hence, any further increase of any of the variables 
included in core FSI (relating to banks) will continue to translate to hoarding of more financial resources which will further exacerbate decreases in growth rate. Also, unit root tests that consider the presence of structural breaks should be used instead of conventional unit root tests in ascertaining stationarity of variables in all literature concerning financial stability.

In sum, the goal of financial authorities must be attaining the optimum level of financial stability that influence and sustains economic growth and not attaining higher levels of financial stability index which has adverse effect on economic growth. This study recommends to the apex bank that the FSSI can be employed as an important tool in gauging the influence of financial or economic policy measures on financial stability and its corresponding impact on economic performance. This study was confined to investigating and drawing empirical relationships between financial system stability and economic growth in Nigeria; results of which have shown that excessive increase in financial system stability reduces economic growth rate. Determining the threshold beyond which financial system stability begins to cause negative growth was beyond the purview of this work. There is need therefore for the apex bank to fund researches that will seek to determine this threshold for the Nigerian financial system. This will guide the formulation and implementation of monetary policy, and the overall attainment of economic growth and development in Nigeria.

\section{Declarations}

\section{Availability of data and materials}

The data for this present study are sourced from the database of the statistical bulletin of Nigeria CBN (https://www.cbn.gov.ng/) World Development Indicators (https://data.worldbank.org/) and International Monetary Fund data (www.inf.org) $)^{5}$.

\section{Competing interests}

Authors wish to disclose here that there are no potential conflicts of interest at any level of this study.

\section{Funding}

Authors hereby declare that there is no form of funding received for this study.

\section{Authors' contributions}

\footnotetext{
${ }^{5}$ The current data specific data can be made available upon request but all available and downloadable at the earlier mentioned database and web link
} 
The first author (Isaac Ikeafe NJANG) was responsible for the conceptual construction of the study as well as the literature section. The second author (Eko Eko OMINI) handled the data gathering, preliminary analysis and simulation. The third author (Festus Victor BEKUN) proceeded to interpretation of the simulated results and finally the fourth author (Festus Fatai ADEDOYIN) was responsible for proofreading and manuscript editing.

\section{Acknowledgments}

The authors are indebted to the editor and reviewers for constructive comments that have helped improve the quality of the manuscript.

\section{References}

Adeyemi, B. (2011). Bank failure in Nigeria: A consequence of capital inadequacy, lack of transparency and non-performing loans? Bank and Bank Systems, 6(1), 99-109.

Ahmed, K., Bodjongo, M. J. M., \& Abid, I. (2015). Financial development, financial instability and economic growth: The case of maghreb countries. International Journal of Economics and Financial Issues, 5(4), 1043-1054.

Akosah, N., Loloh, F., Lawson, N., \& Kumah, C. (2018). Measuring Financial Stability in Ghana: A new Index-Based Approach (Munich Personal RePEc Archive No. 86634). Accra.

Arzamasov, V., \& Penikas, H. (2014). A financial stability index for Israel. Tel Aviv, Isreal: Procedia.

Batuo, E., Mlambo, K., \& Asongu, S. (2017). Linkages between financial development, financial instability, financial liberalization and economic growth in Africa (No. 17/030). Westminster: International Business and Finance.

Blake, M., Keller, K., Moynihan, T., Elliott, D., Black, P., \& Wyman, O. (2017). Balancing financial stability, innovation and economic growth. Cologny/Geneva, Switzerland.

Bozovic, M. L., \& Smolovic, J. C. (2016). Evidence on economic growth and financial development in Montenegro. Journal of Management Sciences, 11(4), 349-365.

Brave, S., \& Butters, R. A. (2011). Monitoring financial stability : A financial conditions index approach. Economic Perspectives from Federal Reserve Bank of Chicago, 35(1), $22-43$. 
Caprio, G., \& Klingbiel, D. (1999). Episodes of systemic and borderline crisis (Policy Research Paper No. 1620). Washinton D.C.

CBN. (2009). Financial stability report. Abuja, Nigeria.

CBN. (2016). Financial Stability Report. Abuja, Nigeria.

Central Bank Of Nigeria. (2009). Financial stability report: Maiden Edition. Abuja, Nigeria.

Cheang, N., \& Choy, I. (2009). Aggregate financial stability index for an early warning system (Macao Monetary Research Bulletin No. 21). Macau.

Čihák, M., Demirgüç-Kunt, A., Feyen, E., \& Levine, R. (2012). Benchmarking financial systems around the world (Policy Research Working Paper Series No. 6175). London: The World Bank.

Creel, J., Hubert, P., \& Labondance, F. (2013). Financial stabilty and economic performance (No. 01064263). Paris: HAL.

Dhal, S., Kumar, P., \& Ansari, J. (2011). Financial stability , economic growth , inflation and monetary policy linkages in India: An empirical reflection. Reserve Bank of India Occassional Papers, 32(3), 4-46.

Drambi, L. Y., Adzu, A., Samson, R., \& Lugu, C. (2015). Financial deepening and economic development of Nigeria : An empirical investigation (1981-2013 ). European Journal of Business and Management, 7(33), 105-124.

Eta, A. E., \& Anabori, M. B. (2015). Financial sector reforms and economic growth in Nigeria. International Journal of Economics, Commerce and Management, III(9), 150171.

Fadare, S. O. (2011). Banking crisis and financial stability in Nigeria. International Research Journal of Finance and Economics, 63(63), 200-205.

Gambacorta, L. (2011). Do bank capital and liquidity affect real economic activity in the long run? A VECM analysis for the United States. Economic Notes, 40(3), 75-91.

Ibrahim, M., Tamene, M., Tapsoba, S., \& Swiston, A. (2017). International Monetary Fund. Nigeria, Selected issues (IMF Country Report No. 17/81). Washinton D.C. 
Indrajit, R., Dipankar, B., \& Arti, S. (2015). Financial conditions composite indicator (FCCI) for India (IFC Bulletin No. 39). Basel.

International Monetary Fund. (2006). Financial Soundness Indicators: Compilation Guide, International Monetary Fund, March. Washinton D.C, United States.

International Monetary Fund Data. (2017). Gross domestic growth for Nigeria: 1986 to 2016.

Knoema. (2017). Gross domestic product growth rate. Retrieved 27 March 2017, from https://knoema.com/atlas/Nigeria/topics/Economy/National-Accounts-Gross-DomesticProduct/GDP-growth

Lee, J., \& Strazicich, M. C. (2001). Testing the null of stationarity in the presence of a structural break. Applied Economics Letters, 8(6), 377-382. https://doi.org/10.1080/135048501750237810.

Levine, R., Loayza, N., \& Beck, T. (2000). Financial intermediation and growth : Causality and causes. Journal of Monetary Economics, 46(2000), 31-77.

Locarno, A. (2011). The macroeconomic impact of Basel III on the Italian economy. (Bank of Italy occasional papers No. 88). Rome.

Mingione, F. (2011, August). Forecasting with principal components analysis: An application to financial stability indices for Jamaica. Kingston, Jamaica: Bank of Jamaica.

Nasreen, S., \& Anwar, S. (2017). How financial stability affects economic development in South Asia : A panel data analysis. European Online Journal of Natural and Social Sciences, 7(1), 54-66.

Ngwube, A., \& Ogbuagu, M. (2014). Global financial crisis and Nigeria economy. Global Journal of Management and Business Research: Economics and Commerce, 14(4), 3-7.

Obienusi, I., \& Obienusi, E. (2015). Banking reforms and the Nigerian economy, 1990 2007. (Historical Research Letter No. 21). Historical Research Letter (Vol. 21). Awka, Nigeria.

Ochei, A. I. (2012). Bank capitalisation, management and performance: A case study of Nigerian banking industry (commercial bank 1986-2006). Berlin, Germany: Lambert Academic Publishing. 
Ogege, S., Williams, H. T., \& Emerah, A. (2012). An empirical analysis of capital adequacy in the banking sub-sector of the Nigeria Economy. International Journal of Economics and Finance, 4(5), 208-215. https://doi.org/10.5539/ijef.v4n5p208

Ogujiuba, K., \& Obiechina, M. E. (2011). Financial sector reforms in Nigeria : Issues and challenges. International Journal of Business and Management., 6(6), 222-233. https://doi.org/10.5539/ijbm.v6n6p222

Ogwumike, F. O., \& Salisu, A. A. (2008). Financial development and economic growth in Nigeria. Journal of Monetary and Economic Integration, 12(2), 92-103.

Oladejo, O. M., \& Oladipupo, A. U. (2011). Capital regulation and the performance of the Nigerian banks : Need for review. Journal of Emerging Trends in Economics and Management Sciencies, 2(3), 215-224. Retrieved from ournal of Emerging Trends in E

Olukotun, G. A., James, O. O., \& Olorunfemi, K. (2013). Bank distress in Nigeria and the Nigeria deposit insurance corporation intervention. Global Journal of Management and Business Research Finance, 13(8), 2-14.

Omolara, C., \& John, A. A. (2016). Financial sector reforms and output growth in manufacturing : Empirical evidence from Nigeria. American International Journal of Contemporary Research, 6(3), 112-125.

Omoruyi, A., \& Ede, A. U. (2014). Financial system development and economic growth the Nigerian stock market and bank perspective. Asian Journal of Business Mnangement, 6(4), 155-172.

Orji, A., Ogbuabor, J., \& Anthony-orji, O. (2015). Financial liberalization and economic growth in Nigeria : An empirical evidence. International Journal of Economics and Financial Issues, 5(3), 663-672.

Sere-Ejembi, A., Udom, I. S., Salihu, A., Atoi, N. V., \& Yaaba, B. N. (2014). Developing banking system stability index for Nigeria. CBN Journal of Applied Statistics, 5(1), 4977.

Shrestha, M. B., \& Chowdhury, K. (2005). A sequential procedure for testing unit roots in the presence of structural break in time series data (Faculty of Business-Economics Working Papers No. 5-6). Sydney. 
Soludo, C. C. (2004). An address by the CBN governor at the special meeting of the bankers committee in Abuja on 6th July 2004. In Consolidating the Nigerian banking industry to meet the development challenges of the 21st century. An Address by the CBN Governor at the Special Meeting of the Bankers Committee in Abuja on 6th. Abuja, Nigeria: Central Bank of Nigeria.

Svirydzenka, K. (2016). Introducing a new broad-based index of financial development (IMF Working Papers No. WP/16/5). Washinton D.C.

Udom, I., \& Doguwa, S. I. (2015). Generating a composite index to support monetary and financial stability analysis in Nigeria. Bank for International Settlements, 39(5), 1-13.

Udom, I., Eze, R., \& Inim, V. (2018). An evaluation of financial system stability in Nigeria. Global Advanced Research Jornal of Management and Business Studies, 7(1), 31-37.

Udude, C. (2014). Financial development and economic growth in Nigeria (1980-2012). International Journal of Social Sciencies and Humanities Reviews, 4(4), 198-204.

Ugwuanyi, C. U., Odo, S. I., \& Ogbonna, B. (2015). Impact of financial development indicators on economic growth in Nigeria, 1980 - 2013. Journal of Economics and Sustainable Development, 6(24), 79-83.

Umoru, D., \& Osemwegie, J. O. (2016). Capital adequacy and financial performance of banks in Nigeria : Empirical evidence based on the Fgls estimator. European Scientific Journal, 12(25), 295-305.

Yusifzada, L., \& Mammadova, A. (2015). Financial intermediation and economic growth (No. 1091). Michigan.

\section{Appendixes}




\begin{tabular}{|c|c|c|c|c|c|c|}
\hline \multicolumn{7}{|c|}{ UNIT ROOT TEST WITH STRUCTURAL BREAKS } \\
\hline \multicolumn{7}{|c|}{ AT LEVEL I(0) } \\
\hline & \multicolumn{3}{|c|}{ Perron 97} & \multicolumn{3}{|c|}{ Lee Strazicich } \\
\hline Variables & t-Stat & $\mathrm{BP}$ & DECISION & t-Stat & $\mathrm{BP}$ & DECISION \\
\hline \multirow{2}{*}{ FSSI } & -3.977 & \multirow{2}{*}{2005} & \multirow{2}{*}{ Unit root } & -5.491 & \multirow{2}{*}{ 98/01 } & \multirow{2}{*}{ Unit root } \\
\hline & $(-5.92)$ & & & $(-6.750)$ & & \\
\hline \multirow{2}{*}{ GDP } & -4.436 & \multirow{2}{*}{2001} & \multirow{2}{*}{ Unit root } & -4.838 & \multirow{2}{*}{$96 / 2000$} & \multirow{2}{*}{ Unit root } \\
\hline & $(-6.32)$ & & & $(-6.750)$ & & \\
\hline \multirow{2}{*}{ INTR } & -3.207 & \multirow{2}{*}{1998} & \multirow{2}{*}{ Unit root } & -6.061 & \multirow{2}{*}{$96 / 03$} & \multirow{2}{*}{ Weak } \\
\hline & $(-6.32)$ & & & $(-5.893)^{* * *}$ & & \\
\hline \multirow{2}{*}{ INFR } & -7.945 & \multirow{2}{*}{1995} & \multirow{2}{*}{ Stationary } & -5.448 & \multirow{2}{*}{ 98/07 } & \multirow{2}{*}{ Unit root } \\
\hline & $(-6.32)^{*}$ & & & $(-6.932)$ & & \\
\hline \multirow{2}{*}{ NEXR } & -3.803 & \multirow{2}{*}{1998} & \multirow{2}{*}{ Unit root } & -16.579 & \multirow{2}{*}{$97 / 13$} & \multirow{2}{*}{ Stationary } \\
\hline & $(-6.32)$ & & & $(-6.821)^{*}$ & & \\
\hline \multirow{2}{*}{ GCF\%GDP } & -4.286 & \multirow{2}{*}{2008} & \multirow{2}{*}{ Unit root } & -7.077 & \multirow{2}{*}{ 2004/2007 } & \multirow{2}{*}{ Stationary } \\
\hline & $(-5.92)$ & & & $(-6.863)^{*}$ & & \\
\hline
\end{tabular}

II.

Pair wise Granger Causality Test

\begin{tabular}{|c|c|c|c|}
\hline Null Hypothesis: & Obs & F-Statistic & Prob. \\
\hline FSSID1 does not Granger Cause GDPD1 & 28 & 3.51932 & 0.0464 \\
\hline GDPD1 does not Granger Cause FSSID1 & & 0.71304 & 0.5007 \\
\hline GCF_OF_GDPD1 does not Granger Cause GDPD1 & 28 & 4.77646 & 0.0184 \\
\hline GDPD1 does not Granger Cause GCF_OF_GDPD1 & & 0.42544 & 0.6585 \\
\hline INFRD1 does not Granger Cause GDPD1 & 28 & 4.09661 & 0.0301 \\
\hline GDPD1 does not Granger Cause INFRD1 & & 1.63273 & 0.2172 \\
\hline INTRD1 does not Granger Cause GDPD1 & 28 & 1.71068 & 0.2029 \\
\hline GDPD1 does not Granger Cause INTRD1 & & 4.31658 & 0.0256 \\
\hline NEXRD1 does not Granger Cause GDPD1 & 28 & 0.21767 & 0.8060 \\
\hline GDPD1 does not Granger Cause NEXRD1 & & 0.01366 & 0.9864 \\
\hline GCF_OF_GDPD1 does not Granger Cause FSSID1 & 28 & 0.29908 & 0.7443 \\
\hline FSSID1 does not Granger Cause GCF_OF_GDPD1 & & 2.08480 & 0.1472 \\
\hline INFRD1 does not Granger Cause FSSID1 & 28 & 1.40706 & 0.2652 \\
\hline FSSID1 does not Granger Cause INFRD1 & & 0.35687 & 0.7037 \\
\hline INTRD1 does not Granger Cause FSSID1 & 28 & 1.33608 & 0.2825 \\
\hline
\end{tabular}


FSSID1 does not Granger Cause INTRD1

$0.29481 \quad 0.7474$

\begin{tabular}{cccc}
\hline \hline NEXRD1 does not Granger Cause FSSID1 & 28 & 2.11473 & 0.1435 \\
FSSID1 does not Granger Cause NEXRD1 & 0.23946 & 0.7890 \\
\hline \hline INFRD1 does not Granger Cause GCF_OF_GDPD1 & 28 & 0.04596 & 0.9552 \\
GCF_OF_GDPD1 does not Granger Cause INFRD1 & 2.60130 & 0.0958 \\
\hline \hline INTRD1 does not Granger Cause GCF_OF_GDPD1 & 28 & 1.97916 & 0.1610 \\
GCF_OF_GDPD1 does not Granger Cause INTRD1 & 0.28405 & 0.7553 \\
\hline \hline NEXRD1 does not Granger Cause GCF_OF_GDPD1 & 28 & 0.88178 & 0.4276 \\
GCF_OF_GDPD1 does not Granger Cause NEXRD1 & 0.19921 & 0.8208 \\
\hline \hline INTRD1 does not Granger Cause INFRD1 & 28 & 0.46591 & 0.6334 \\
INFRD1 does not Granger Cause INTRD1 & & 4.22260 & 0.0274 \\
\hline \hline INTRD1 does not Granger Cause NEXRD1 & & 0.36433 & 0.6986 \\
\hline \hline NEXRD1 does not Granger Cause INFRD1 & 28 & 0.07151 & 0.9312 \\
INFRD1 does not Granger Cause NEXRD1 & & 0.27232 & 0.7640 \\
\hline \hline
\end{tabular}

III.

\begin{tabular}{|c|c|c|c|c|c|c|}
\hline \multicolumn{7}{|c|}{ VAR Lag Order Selection Criteria } \\
\hline \multicolumn{7}{|c|}{ Endogenous variables: GDP FSSI GCF_OF_GDP INFR INTR_NEXR } \\
\hline Exogenous variables: C. Sample: 1986 2016. Included observations: 29 \\
\hline Lag & LogL & LR & FPE & AIC & SC & HQ \\
\hline 0 & -529.3 & NA & $4.35 E+08$ & 36.91723 & 37.20012 & 37.00583 \\
\hline 1 & -426.888 & 155.3831 & 4724006 & 32.33712 & $34.31734 *$ & 32.9573 \\
\hline 2 & -376.888 & $55.17273 *$ & $2559952 . *$ & $31.37159 *$ & 35.04914 & $32.52335^{*}$ \\
\hline * indicates lag order selected by the criterion & & \\
\hline \multicolumn{7}{|c|}{ LR: sequential modified LR test statistic (each test at 5\% level) } \\
\hline
\end{tabular}

IV. 


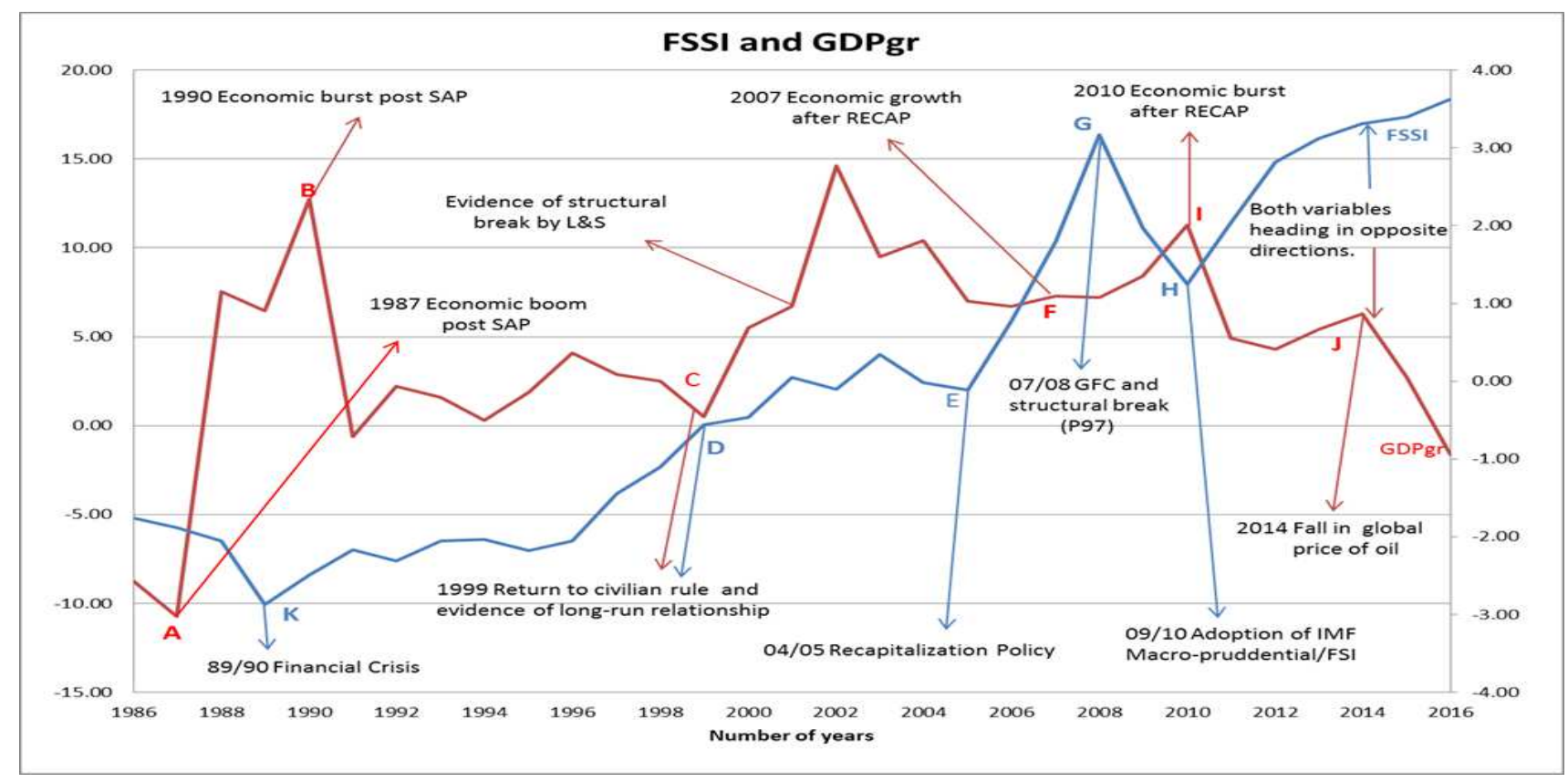

\section{Diagnostic Tests}

V.

Breusch-Godfrey Serial Correlation LM Test

\begin{tabular}{cccc}
\hline \hline F-statistic & 0.426338 & Prob. F(2,19) & 0.6590 \\
Obs*R-squared & 1.245555 & Prob. Chi-Square(2) & 0.5365 \\
\hline \hline
\end{tabular}

VI.

Heteroskedasticity Test: Breusch-Pagan-Godfrey

\begin{tabular}{cccc}
\hline \hline F-statistic & 0.736366 & Prob. F(12,16) & 0.7004 \\
Obs*R-squared & 10.31774 & Prob. Chi-Square(12) & 0.5881 \\
Scaled explained SS & 5.241490 & Prob. Chi-Square(12) & 0.9494
\end{tabular}


VII.

Normality Test

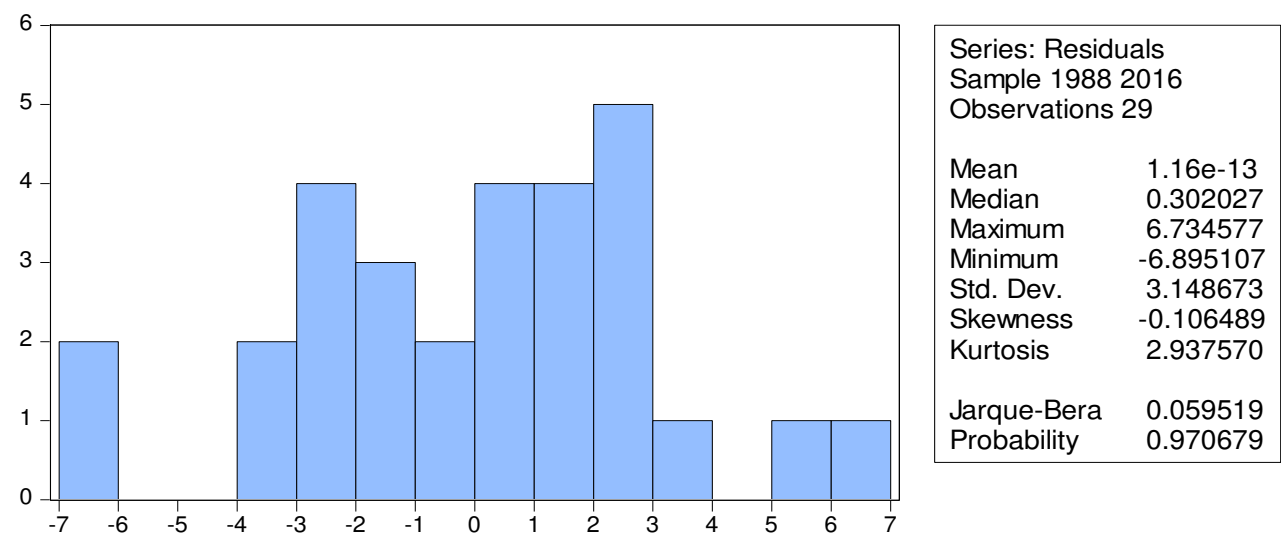

VIII.

CUSUM Stability Test

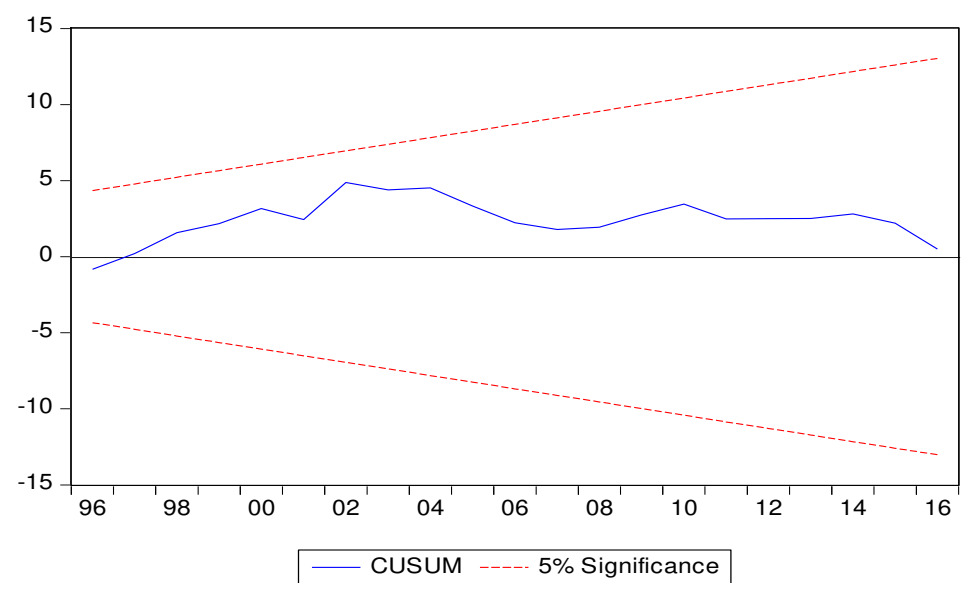

IX.

Variance Decomposition of GDP:

\begin{tabular}{|r|l|r|r|r|r|r|r|}
\hline Period & S.E. & GDP & FSSI & GCF & INFR & INTR_ & NEXR \\
\hline 1 & 3.635774 & 100 & 0 & 0 & 0 & 0 & 0 \\
\hline 2 & 4.333996 & 78.62651 & 3.698028 & 0.101983 & 6.614482 & 10.94144 & 0.017555 \\
\hline 3 & 4.658322 & 68.15242 & 4.990874 & 4.145749 & 7.882417 & 14.14564 & 0.682892 \\
\hline 4 & 4.949169 & 60.54572 & 5.183584 & 5.375372 & 7.134976 & 20.15031 & 1.610034 \\
\hline 5 & 5.235307 & 54.4858 & 5.474775 & 7.296506 & 6.644101 & 23.69482 & 2.404001 \\
\hline
\end{tabular}

